\title{
THE TRANSITION OF NAMES: FROM PROPER NAMES TO COMMON NOUNS
}

\author{
Aleksandra Aleksandrova*
}

\begin{abstract}
The paper deals with proper names' trend to be transformed into common nouns in both Bulgarian and English-language media texts. It traces the mechanisms leading to this transformation- using names in plural form, presence of a definite article, lack of capitalization and use of closed compounds. A combination of those mechanisms contributes further to the common meaning of the expression.
\end{abstract}

Key words: names, shift of meaning, metonymy

\section{Introduction}

Names often shift from one class of words into another. A nickname can become an official personal name (a first name or a surname) while it is also possible for an official name to become a nickname. A shift from proper name to common noun and vice versa is also observed. This shift is metonymically motivated and happens with a name that very often appears in the media and is mentioned in relation with a certain phenomenon or event. The type of metonymy this shift of meaning is based on is prototypical metonymy - the name becomes synonymous with that phenomenon and at a later stage it functions as a common noun. The shift of meaning is indicated by the following features: plurality, use of quantifiers like many, now many, any, etc., lack of capitalization, and use of closed compounds. It is possible for some of those features to be used concurrently.

\section{Previous research on the topic}

According to Jespersen (1990), the transition of some proper names into common ones happens when one quality is selected as the best known, "and is used to characterize some other being or thing possessed of the same quality" (Jespersen, 1990, p. 67). Barcelona (2004) argues that names often originate "as descriptions of a given entity on the basis of a different related entity or circumstance and this type of description constitutes a straightforward instance of metonymy" (Barcelona. 2004, p. 14). Eventually, these descriptors become "rigid designators with unique reference (i.e. they become real names), and

* Assist. Professor PhD at Shumen University, Department of English Studies, Shumen, Bulgaria, e-mail: a.aleksandrova@shu.bg 
this semantic fact constrains their grammatical behaviour to a greater or lesser degree in many languages" (ibid.). However, when names' morphosyntactic behaviour violates these constraints and they start behaving like common noun, there is obviously a metonymic motivation and there often is a metonymically induced change from common nouns to proper names and back to common nouns, which Barcelona calls "a metonymic return ticket" (ibid.). According to Panther and Thornburg (2003), in a prototypical metonymy, which facilitates the shift of meaning discussed in this paper, "the target meaning is more prominent than the source meaning, although the source meaning must of course have a sufficient degree of salience in the context of the utterance in order to be able to activate the target. (Panther, Thornburg, 2003, p. 107). Barcelona (2003) defines prototypical metonymy as a "typical metonymy with individuals as targets and as referents" (Barcelona, 2003, p. 246).

\section{Analysis}

Proper names are capitalized and cannot be used in plural. Yet, it is possible for a name to appear in plural form, uncapitalized, accompanied by a quantifier, or as a closed compound in both English and Bulgarian media texts, thus shifting its meaning from proper to common.

\subsection{Plurality}

When used in plural, names stand for a type of people, considered to possess a quality ascribed to the individual in the metonymic source:

"When he ran for mayor in Burlington initially he was a real long shot, he ended up winning by 10 votes, I think, because people believed in him," Jerry added.

Now the town has an open waterfront which is enjoyed by everyone.

It was the first of many battles fought by Mr Sanders, and even a cursory stroll around the town and the crudest of straw polls demonstrated that the affection for the most unlikely of political Don Quixotes remains powerful in his home town. https://www.telegraph.co.uk, 17/08/2015)

\subsection{Use of quantifiers}

Names in plural form can be accompanied by quantifiers like many, how many, many $a$, etc. In the following excerpt, the expression how many Picassos means 'how many people with great artistic talent':

Graffiti was born from inner city neighborhoods as a way to express the community's inner feelings and frustrations. Their works normally have a message for people to interpret or to decode. And, until now, these messages have been largely ignored. "It's sad to think about how many Picassos were overlooked because no one took the time to mentor or nurture the gift," says abstract artist Floy Ealy Edjole. (www.retrosektart.com, 26/06/2016) 
In the next excerpt from The Economist, Mozarts, Michelangelos and Einsteins in the metonymic source activate concepts 'genius composers', 'prominent sculptors and painters' and 'eminent physicists':

This is dangerous territory. Some experts take the view that more people mean more problems. But every economist is also a human being subverted by his prejudices. Mr Simon was opposed to birth control, although not for reasons of faith: he was a Jew, not a Roman Catholic. He just felt it was wrong, but he sought to give some logic to his prejudice by asking how many Mozarts, Michelangelos and Einsteins had been lost to the world by birth control. A tricky question. Are Michelangelos the inevitable products of fecund communities or the fortunate accidents of small and specialised civilisations? (https://www.economist.com/node/604696)

It should be mentioned that the quality which activates the target is the most salient feature of the referent - the trend the individual in the source notion is mostly associated with. For instance, it is known that Einstein, apart from a brilliant scientist, was a masterly violinist, but this quality does not activate a target with such meaning. Michelangelo was not only painter and sculptor, but also an architect and a poet, yet the metonymic source Michelangelo activates the concept 'genius sculptor', or 'genius painter'.

\subsection{Use of adjectives}

Names in plural can be accompanied by adjectives like new, future, etc. In the next excerpt, new Saladins and new Lionhearts stand for people who are likely to start religious wars in the future:

The moral is the message: the crusades were "madness" and massacre, "unprecedented before Hitler". The scholarship is unsearching. Without the background of Zengid politics or Islamic schisms, and without the context of the conflicts of Christendom, it is impossible for the reader to make real sense of Saladin, or a real king of Richard. Still, Mr Reston has a timely warning against loose talk of new crusades today: nothing is more likely to stir up new Saladins - or on the rebound, you could add, new Lionhearts. (The Economist, 18/10/2001)

In the next excerpt, Future Mozarts stands for people who have already found their talent in music and started working on its development and popularization:

Classical music; For Future Mozarts, No Place To Shine?

Music's growth period, though, is long over - or rather, the growth long ago moved elsewhere, to popular music...... All of this could simply mean that the orchestra and the concert are redundant institutions, and that in the last half-century another technology, that of recording, has taken over their role in providing access to performed music. (The New York Times, 24/05/2008) 


\subsection{Uncapitalized names in plural}

Unlike English-language texts, in Bulgarian texts it is possible for names to be uncapitalized when they function as common nouns. In the next excerpt, симеончовии is the plural form of Симеончо, which is the diminutive form of Симеон. Симеон is the name of the Bulgarian tsar Boris III's son:

Много съжалявам за загубата. Аз и ръководството осигуряваме на футболистите всичко необходимо, живеят си като „симеончовци”. Нищо повече не искам да говоря (http://www.novsport.com/ news142439_1068.html, 04/05/2011)

I am really sorry for the loss. I and the management provide our football players with everything they need, they live like the young Simeon."

The popular phrase "живея/живееш/живеят си като Симеончо" (to live like the young Simeon) means to live very well. Uncapitalizing the name and using it in plural form shifts it more towards a common noun.

\subsection{Pluralized names with the definite article}

When used with a definite article, names have a meaning that can be expressed in the following way:

$\mathrm{X}_{\text {(a person ascribed certain qualities) }} \rightarrow$ The $\mathrm{Xs}_{\text {(a group of people having one of the qualities }}$ ascribed to X)

In the next excerpt, Гинките is used for people who have managed to sign an important contract in a dubious way:

За Гинките и хората...

В момента България за едни е страната на неограничените възможности, за други пък е просто лоша майка (мащеха), към която е все по трудно да изпитваш обич. Хора и ситуации всякакви, но едно е сигурно-абсурдите никога няма да свършат. И докато едни се чудят как да преживеят с минималната си заплата и да си купят вечеря, други с уверен размах си купуват неща от сорта на...ЧЕЗ...Става дума за доскоро обгърнатата в мистерия Гинка Върбакова, която купи активите на ЧЕЗ и която по-късно надълго и на широко обясняваше по интервюта, че е направила заветната сделка чрез собствена фирма и никой не стои зад гърба ѝ. https:// www.actualno.com/curious/za-ginkite-i-horata-news_663717.html

About the Ginkas and the people.

\footnotetext{
* Translation mine.
} 
At present, for some people Bulgaria is the land of unlimited possibilities, while for others it is just a bad mother (a stepmother), who gradually becomes hard to love. There are all kinds of people and situations, but one thing is for sure- the absurd ones will never come to an end. And while some people it is hard to make ends meet on a minimum pay, others quite confidently buy something like...CEZ* The case in point is the mysterious Ginka Varbakova, who bought the assets of CEZ and who later on explained at length that she finalized the cherished deal via her own company and nobody is backing her up. **

The above text demonstrates that common nouns derived from proper names can be used with a negative connotation. This use can be achieved by the context in which the name appears. In the above excerpt, the name Гинките is used in plural and is juxtaposed with the word xopama, meaning 'people'. By this juxtaposition it is implied that the name bearer is considered as something different from a person. The negative attitude is even stronger in the next excerpt, where the name is again used in plural and it is not capitalized. It is also evident in the use of vocabulary from the domain of animals and animal husbandry:

Глобално ни показаха как калинките***, при подходящ режим на отглеждане,

могат да пораснат до гинки, а някои от най-добрите гинки могат да станат даже милионерки. https://varnautre.bg/

It was globally demonstrated how the kalinkas, with an appropriate husbandry routines can grow to ginkas, and some of the best ginkas can even become millionaires. ${ }^{* * * *}$

\subsection{Closed compounds in plural}

With closed compound, the shift happens in several steps. First, a common noun used with a proper name becomes part of the proper name. When it becomes well established, it is capitalized. As a result, names like Бай Ганьо, Райна Княгиня, Дон Кихот/ Don Quixote were created. In those cases, a transition from common noun to a proper name is observed. Then, when one

\footnotetext{
* ČEZ Group (Czech: 'Skupina ČEZ' České Energetické Závody) is a conglomerate of 96 companies (including the parent company $\mathbf{C} \mathbf{E Z}$, a.s.), 72 of them in the Czech Republic. Its core business is the generation, distribution, trade in, and sales of electricity and heat, trade in and sales of natural gas, and coal extraction (www.wikipedia.org)

** Translation mine.

*** „,калинка”, which is the Bulgarian word for a ladybird, functions as a common noun for someone who has been appointed on some high-level administrative position on political grounds without having the necessary qualification. This figurative meaning of "калинка", originates from the name of the director of State Fund Agriculture, Kalina Ilieva, who became notorious for her inexpedient appointment. The etymological meaning of Kalina is the word „калина” (mountain ash). Then there is a shift in meaning from common to proper noun. Then, the associative meaning of Kalina as someone who has been appointed on some high-level administrative position without having the necessary qualifications is transferred to the noun калинка. Калинка (ladybird) is the diminutive form of Калина, which is aimed at achieving a derisive effect. (see Aleksandrova 2016)
}

***** Translation mine 
quality attributed to name's referent is selected and is applied to another referent or a list of referents, who are believed to possess the same quality, the newly created expression is spelled as one word and function as a common noun. The plural form of the compound brings it even closer to a common noun. In the next excerpt, the expression Донкихотовии is used to stand for people who are "determined to change what is wrong, but who does it in a way that is silly or not practical" (www.ldoceonline.com):

Заветите на Ботев и съвременните Донкихотовци

Зарекохме се да помним патриотизма на знайните и незнайни българи, загубили живота си в името на родината. Но само ден след това ще сме забравили за тези думи. Нека поне си спомним за духовността и историята, за онази борба с вятърни мелници, която ни прави съвременни Донкихотовци. Защото ги има и такива. И те са тези, за които родната страна не е мащеха. (https://www.monitor.bg)

\section{Botev's legacy and the contemporary Don Quixotes}

We promised to remember the patriotism of the known and unknown Bulgarians who lost their lives in the name of their motherland. But just a day later we will forget those words. Let us recall the spirituality and history, the fight against windmills which makes us contemporary Don Quixotes. Because they do exist. And they are those whose motherland is not their stepmother.

Closed compounds can have positive or negative connotations. This does not depend on the context, but rather on the quality attributed to its original referent. In the following excerpt, Байганьовичи is used to stand for a common, plain, clumsy uncouth people:

\section{Комунистически Байганьовци, неразбиращи чужди езици, разузнават по света от името на ДС}

Тайните служби на червената власт - неграмотност и талант единствено да служат за лош пример https:/www.faktor.bg/bg/articles/ petak-13/-komunisticheski-bayganyovtsi-nerazbirashti-chuzhdi-ezitsirazuznavat-po-sveta-ot-imeto-na-ds- 84177

Communist Baiganjovtsi who do not speak any foreign language, reconnoitre the world on behalf of The Committee for State Security.

The Red authority's secret services- illiteracy and talent only for the sake of serving as a bad example.*

The use of proper names closed compounds is to be found predominantly in Bulgarian texts, while in the English-language texts they are not so well established.

\footnotetext{
* Translation mine.
} 


\subsection{Uncapitalized closed compounds}

This way of forming common nouns from names is used mainly in Bulgarian media texts, while in English language texts it is not found. In the next excerpt, харипотъровии stands for people interested in illusionism:

\section{Школа за харипотъровци отваря врати в Русе \\ Школа за млади магьосници и последователи на Хари Потър отваря врати в Русе, съобщи собственикът Розен Тодоров. Вече са се записали 24 деца от дунавския град. \\ http://www.segabg.com/article.php?sid=2003042600010140001, 26/04/2003}

\section{A school for Harry Potters opens in Ruse.}

A school for young magicians and Harry Potter's followers opens in Ruse, its owner Rozen Todorov announced. Twenty four children from the Danube city have already enrolled."

\section{Conclusion}

Proper names can serve as common nouns in both English and Bulgarian language. In both languages there is a use of plural forms. The definite article is used with proper names in both languages. A combination of plurality and use of the definite article is present in both languages. Uncapitalization is more frequent in Bulgarian texts and is almost lacking in English-language texts. Closed compounds were found only in English-language texts, while they are well exploited in Bulgarian texts, where they are often uncapitalized.

The use of a plural form, the presence of the definite article, the uncapitalization and the formation of closed compounds are ways of shifting the category of the word from proper to common. A combination of them emphasizes this effect and contributes further to the common meaning of the expression.

\section{References:}

Barcelona, A. (2003). Metonymy in cognitive linguistics. An analysis and a few modest proposals. Motivation in languge. Studies in honour of Günter Radden. Amsterdam: John Benjamins Publishing Company

Barcelona, A. (2004). Names: a metonymic "return ticket" in five languages. Jezikoslovlje. 4.1. 11-41.

Jespersen, O. (1990). Philosophy of grammar. Chicago: University of Chicago Press.

Panther, K-U., \& Thornburg, L. L. (2003). The Role of conceptual metonymy in meaning construction. 8th International Cognitive Linguistics Conference at the University of La Rioja, Logroño, Spain.

\footnotetext{
* Translation mine.
} 


\section{Internet sources:}

Don Quixote. (n.d.) In Longman Dictionary of Contemporary English Online. Retrieved from https://www.ldoceonline.com/dictionary/don-quixote

CEZ. (n.d.) In Wikipedia. Retrieved from https://en.wikipedia.org/wiki/\%C4\%8CEZ Group

\section{Excerpted sources:}

Za Ginkite i horata. (2018, March 9). Actualno.com. Retrieved from https://www.actualno. com/curious/za-ginkite-i-horata-news_663717.html

Julian Lincoln Simon, an optimistic economist, died on February 8th, aged 65 (1998, February 19). The Economist. Retrieved from https://www.economist.com/obituary/1998/02/19/ julian-simon

Reston, J. (2001, October 18). Stirring Stuff. Warriors of God: Richard the Lionheart and Saladin in the Third Crusade. The Economist. Retrieved from https://www.economist. com/books-and-arts/2001/10/18/stirring-stuff

Komunisticheski Bayganyovtsi, nerazbirashti chuzhdi ezitsi, razuznavat po sveta ot imeto na DS. (2016, October 17). Factor.bg Retrieved from https://www.faktor.bg/bg/articles/ petak-13/-komunisticheski-bayganyovtsi-nerazbirashti-chuzhdi-ezitsi-razuznavat-posveta-ot-imeto-na-ds-84177

Yordanova, Y. Йорданова, Я. (2015, June 2). Заветите на Ботев и съвременните донкихотовци. Монитор. Retrieved from https:/www.monitor.bg/bg/a/view/50411

Ivanov, V. (2011, April 4). Ventsi Stefanov: Futbolistite na Slaviya zhiveyat kato "simeonovchi". Nov sport. Retrieved from http://www.novsport.com/news142439_1068. html

Graffiti art walls in your city: An eyesore or beautiful art? (2016, June 26) Retrospektart. Retrieved from https://retrospektart.com/blogs/news/graffiti-art-walls-in-your-city-aneyesore-or-beautiful-art

Millward, D. (2015, August 17). Ben and Jerry back Burlington Bernie for the White House. The Telegraph. Retrieved from https://www.telegraph.co.uk/news/worldnews/ northamerica/usa/11798713/Ben-and-Jerry-back-Burlington-Bernie-for-the-WhiteHouse.html

Griffiths, P. (1998 May 24). Classical musıc; for future Mozarts, no place to shine? New York Times. Retrieved from https://www.nytimes.com/1998/05/24/arts/classical-musicfor-future-mozarts-no-place-to-shine.html

Mollov, R. (2003, April 26). Школа за харопотьровци отвори врати в Rусе. Сега Retrieved from http://www.segabg.com/article.php?sid=2003042600010140001

Gancheva, Sv. (2018, March 3). Genezisyt na ginkite. Varna utre. Retrieved from https:// varnautre.bg/2018/03/03/76011/ 